\title{
Charcoal produced from Attalea tessmannii Burret. fruit wastes
}

\author{
Carvão vegetal produzido de resíduos de frutos de Attalea tessmannii \\ Burret.
}

\author{
Alice Neri da Silva Sousa ${ }^{1}$ (D), Keiti Roseani Mendes Pereira ${ }^{2}$ (D), Ananias Francisco Dias Júnior ${ }^{3}$ (D), \\ Matheus Bertotti Floriani ${ }^{1}$ (D), Martha Andreia Brand ${ }^{1}$ (i) \\ ${ }^{1}$ Universidade do Estado de Santa Catarina - UDESC, Lages, SC, Brasil \\ ${ }^{2}$ Universidade Federal do Acre - UFAC, Rio Branco, AC, Brasil \\ ${ }^{3}$ Universidade Federal do Espírito Santo - UFES, Jerônimo Monteiro, ES, Brasil
}

How to cite: Sousa, A. N. S., Pereira, K. R. M., Dias Júnior, A. F., Floriani, M. B., \& Brand, M. A. (2022). Charcoal produced from Attalea tessmannii Burret. fruit wastes. Scientia Forestalis, 50, e3730. https://doi.org/10.18671/scifor.v50.01

\begin{abstract}
Charcoal produced from wastes from the production of oil from palm fruits contributes to a non-destructive production of the forest, encourages extractivism and complements the income of traditional populations in protected areas. The objective of this research was to determine the quality of charcoal from Attalea tessmannii Burret. fruits produced in a traditional community located in Gregório River State Forest Complex (Complexo de Florestas Estaduais do Rio Gregório), Acre, Brazil, and compare the charcoal of the fruits with traditional charcoal sold for barbecue. Thus, samples of charcoal from Attalea tessmannii fruit wastes from different pyrolysis methods were collected. The following parameters were analyzed: bulk density, moisture content (MC), volatile materials content (VM), ash content (AC) and fixed carbon content $(\mathrm{FC})$ and higher heating value (HHV). Attalea tessmannii fruit waste charcoal had positive characteristics for food cooking: low moisture content (4.22\%) and volatile materials content (5.94\%) and high bulk density $\left(330 \mathrm{~kg} \mathrm{~m}^{-3}\right)$, fixed carbon content (72.11\%) and higher heating value $\left(7,323 \mathrm{kcal}^{\mathrm{kg}}{ }^{-1}\right)$. However, the product has a high ash content. When compared to charcoal already sold for barbecue use, charcoal from Attalea tessmannii fruit waste showed high quality potential to be included in the market, in order to complement the income of the traditional community involved in the production process.
\end{abstract}

Keywords: Bioenergy; Energy sustainability; Pyrolysis; Non-wood product.

\section{Resumo}

O carvão vegetal produzido de resíduos da extração de óleo de frutos de palmeiras contribui para uma produção não destrutiva da floresta, incentiva o extrativismo e complementa a renda das populações tradicionais das unidades de conservação. O objetivo deste trabalho de pesquisa foi determinar a qualidade do carvão vegetal de frutos da espécie Attalea tessmannii Burret. produzido em uma comunidade tradicional localizada no Complexo de Florestas Estaduais do Rio Gregório, Acre, Brasil, e comparar o carvão dos frutos com carvões vegetais tradicionais comercializados para a cocção de alimentos. Para isso, foram coletadas amostras de carvão vegetal de resíduos de frutos de Attalea tessmannii de diferentes métodos de carbonizações. Foram analisadas a densidade a granel, os teores de umidade (TU), de materiais voláteis (TMV), de cinzas (TCZ) e de carbono fixo (TCF) e o poder calorífico superior (PCS). O carvão vegetal do fruto de Attalea tessmannii apresentou características positivas para uso na cocção de alimentos, como baixos teores de umidade $(4,22 \%)$ e materiais voláteis $(5,94 \%)$, elevados: densidade a granel $\left(330 \mathrm{~kg} \mathrm{~m}^{-3}\right)$, de teor de carbono fixo $(72,11 \%)$ e de poder calorífico superior $\left(7323 \mathrm{kcal} \mathrm{kg}^{-1}\right)$. Como pontos negativos para o referido uso, o produto apresenta elevado teor de cinzas (20,65\%). Quando comparado com carvões vegetais já comercializados para uso doméstico, o carvão vegetal do fruto de Attalea tessmannii se mostrou com elevado potencial de qualidade para ser incluído

Financial support: None

Conflict of interest: Nothing to declare.

Corresponding author: martha.brand@udesc.br

Received: 08 June 2021.

Accepted: 26 November 2021.

Editor: Mauro Schumacher

cc (i) This is an Open Access article distributed under the terms of the Creative Commons Attribution License, which permits unrestricted use,

c) distribution, and reproduction in any medium, provided the original work is properly cited. 
no mercado, sendo uma alternativa produtiva para complementar a renda da comunidade tradicional envolvida no processo produtivo.

Palavras-chave: Bioenergia; Sustentabilidade energética; Pirólise; Produto não-madeireiro.

\section{INTRODUCTION}

The plan for the sustainable use of forest products, especially oilseed species from neotropical forests, has the function of maintaining the forest, preserving the environment and generating income in traditional communities (Stachiw et al., 2016). In the natural forests of the Amazon region, one of the botanical families that stand out is Arecaceae, having a wide variety of species. These palm trees stand out from a natural, economic and ecological point of view, in addition to being a relevant part of the diet of human beings in the form of fruits and hearts of palm and even elaborated products such as sweets, beverages, oils and handicrafts (Lima et al., 2003). In Acre state, northern region of Brazil, of the 18 forest typologies that occur, 12 have palm trees, covering around $86 \%$ of the state's territory (Secretaria do Meio Ambiente, 2010). Palm trees participate in extractive economies with an important impact on supplementing the income of traditional populations.

The process of extracting almonds from palm fruits for use in food, pharmaceutical and chemical industries implies the generation of an enormous amount of wastes. In the case of Attalea tessmannii, the residues are the endocarp and mesocarp of the fruit. These components, which are discarded without recovery, could go through thermal processes and be used in energy production systems. This change in behavior enables the achievement of sustainability in this production chain.

Brazil is among the countries that most use renewable energy, and when it comes to bioenergy, the products that stand out the most are charcoal and firewood. The origin of the raw material for this purpose, in its vast majority, comes from wood from planted forests (Eucalyptus and Pinus), from wood wastes of native species, or even from agro-industrial wastes (Soares et al., 2014; Reis et al., 2015). The use of other sources of raw material for the production of charcoal emerges as a potential alternative to reduce the pressure on native forests. In this context, the use of fruits or parts of palm trees allows for the production of charcoal with quality equivalent or superior to that of wood charcoal, enabling a wide energy application of this material (Silva et al., 1986; Teixeira, 2008; Reis et al., 2015; Evaristo et al., 2016; Protásio et al., 2017; Padilha, et al., 2018).

Charcoal is used for various purposes, such as cooking food, barbecue, fireplaces, thermoelectric plants, cement industry, water and beverage purification, pharmaceutical, steel and metallurgical industries, gas mask filters, and more. To be considered of good quality for domestic use, charcoal must have a low moisture content ( $<5 \%)$, high apparent relative density $\left(>280 \mathrm{~g} \mathrm{~cm}^{-3}\right)$, high fixed carbon content $(>75 \%)$, higher heating value $\left(>4500 \mathrm{kcal} \mathrm{kg}^{-1}\right)$, low volatile materials (<25\%) and a low ash content (<2.5\%) (Neves et al., 2011; Dias Júnior et al., 2020; Dias Júnior et al., 2021). In addition, charcoal is expected to have good combustion and not compromise the environment and human health through potentially toxic gas emissions in the smoke (Dias Júnior et al., 2015; Dias Júnior et al., 2017).

In order to standardize the quality of charcoal for domestic use, São Paulo state, Brazil, was the first and only Brazilian state to create a voluntary resolution, called "Premium Charcoal Seal" - SAA n. 40 of 2015. This regulation assigns minimum quality requirements for the characteristics of charcoal for domestic use, and for meeting legal, environmental and social requirements during its production (São Paulo, 2015). In Europe, for example, the EN 1860-2 (European Committee for Standardization, 2005) standard regulates the quality of charcoal and appliances to be used in the domestic environment.

The existence of this standardization initiative and of several studies on the use and quality of charcoal for cooking food (Rosa et al., 2012; Brand et al., 2015; Costa et al., 2017; Monteiro et al.,2019, Oliveira et al., 2019; Anater et al., 2019; Dias Júnior et al., 2015, 2017, $2020,2021)$ shows the relevance of this theme. However, the limited amount of information on the potential of palm trees for energy purposes, especially of Attalea tessmannii, shows the 
importance and contribution of this study to the investigation of charcoal quality and valorization of this product. This could result in an improvement in the quality of life and income of traditional populations in the Amazon area.

Considering the existence of some studies that found that charcoal from species in the genus Attalea have the desired quality properties for cooking food (Reis et al., 2015; Protásio et al, 2017), the hypothesis is that the charcoal from the wastes of Attalea tessmannii fruits could qualify for this purpose. Thus, the aim of this research was to investigate the quality of charcoal from Attalea tessmannii. fruits from a traditional community located in the Gregório River State Forest Complex, Acre, northern Brazil, and to compare the charcoal of the fruits with traditional charcoal sold for cooking food.

\section{MATERIAL AND METHODS}

The charcoal used in this study was produced from fruit wastes (mesocarp and endocarp) of the Attalea tessmannii Burret. palm tree. These wastes were generated in the process of extracting the almonds for oil production. This species is native to the neo-tropical rainforest of Northern Brazil. The charcoal was collected at the Cooperative of Family Producers and Solidary Economy of the Mogno State Forest (COOPERMOGNO), located in the Gregório River State Forest Complex, municipality of Tarauacá, Acre, Brazil (latitude: $8^{\circ} 8^{\prime} 8^{\prime \prime}$ south, longitude: $70^{\circ} 45^{\prime}$ 54" west, 179 a.s.l.) (Figure 1).

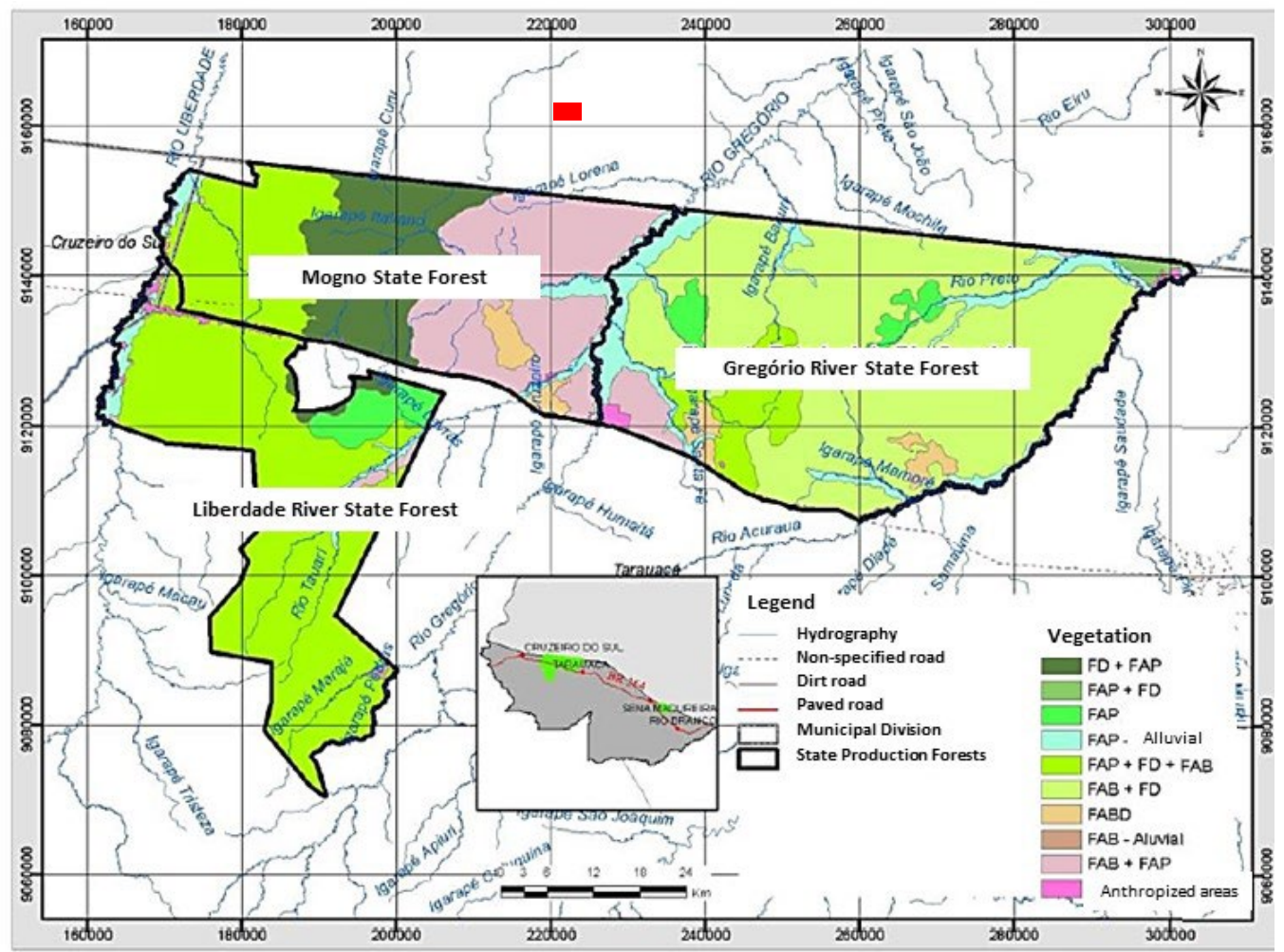

Figure 1: COOPERMOGNO location map in the Gregório River State Forest Complex - CFERG, Municipality of Tarauacá, Acre, Brazil. Source: Secretaria do Meio Ambiente (2019).

Legend: Vegetation - FD: Dense Forest; FAP: Open Forest with Palm Trees; FAB: Open Forest with Bamboo; FABD: Open Forest with Palm Trees and Bamboo.

The fruits were collected manually from the ground, after ripening. After collection, the fruits were transported to the cooperative by the producers (Figure 2A). Charcoal was produced from fruit wastes, after removing the almonds (Figures $2 \mathrm{~B}$ and $2 \mathrm{C}$ ). 

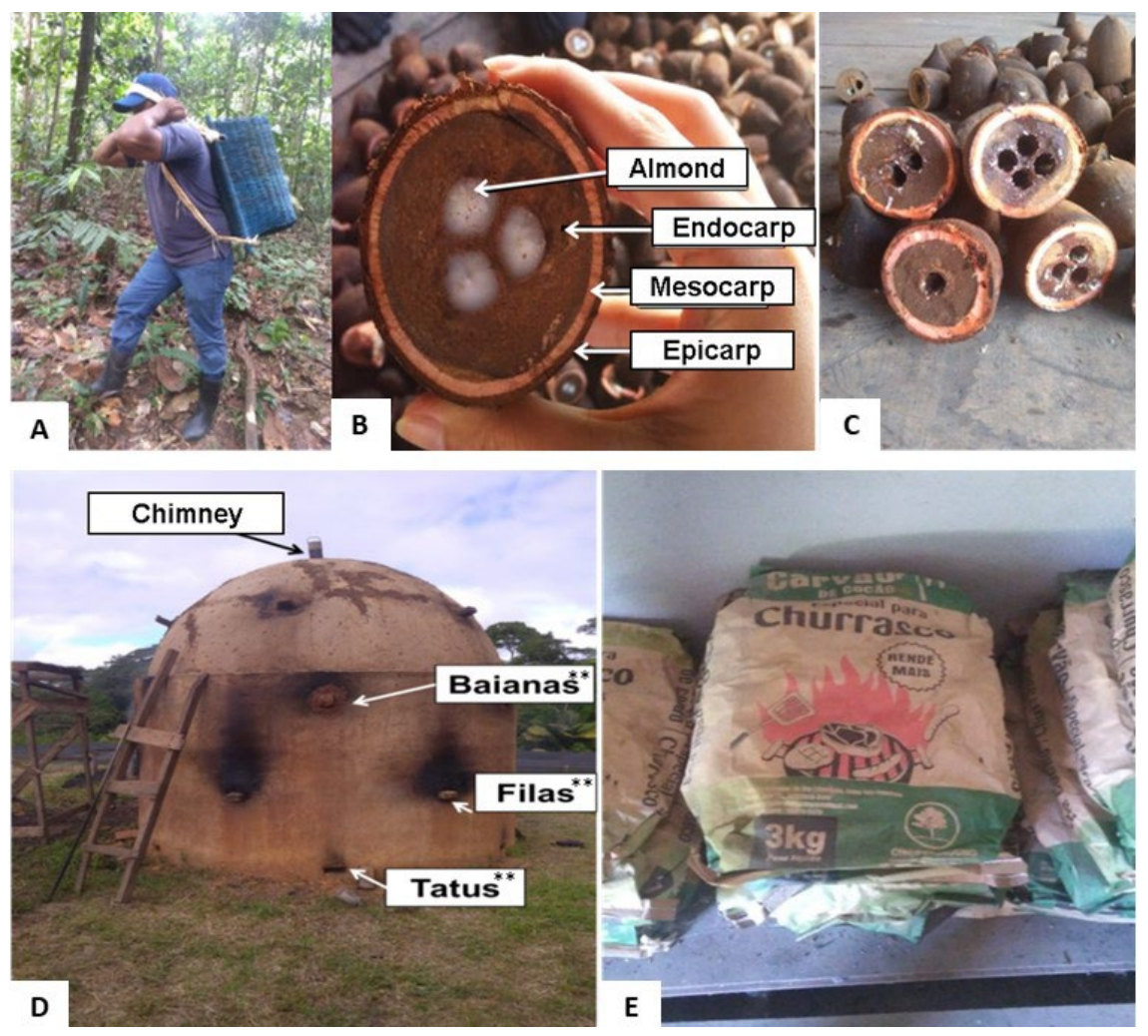

Figure 2: Transport of Attalea tessmannii fruits using caçoá. B - Fruits after being cut in half, identifying their constituent parts. C - Fruits after almond extraction (endocarp). D - Oven of the hot tail type. ** In

Brazil, the nomenclatures of rows of holes such as: "baianas, filas and tatus" are used to name the smoke inlets and outlets of ovens of the "hot tail" type. E - Storage of Attalea tessmannii fruit charcoal bags on pallets.

Charcoal was produced in a hot tail oven with a production capacity of 5 tons of Attalea tessmannii fruits (Figure 2D). The carbonization process is carried out empirically, with monitoring of the internal temperature according to the color of the smoke, and accordingly closing the air inlet holes. The carbonization time lasts on average between 7 and 10 days (between carbonization and cooling) depending on weather conditions. After the oven has cooled down, the charcoal is removed with the aid of a shovel, packaged and stored for later commercial sale (Figure 2E).

To characterize the charcoal from Attalea tessmannii, samples from four carbonizations produced in the cooperative were used (Table 1). Sampling was carried out once. The samples collected had different storage times in the cooperative shed. Each study treatment remained for different storage periods in the cooperative until the date of collection, carried out in August 2019. The charcoals containing only endocarp (T1 and T2) came from carbonization carried out with old fruits, with degradation of the epicarp and mesocarp, while they remained on the forest floor. Charcoals containing endocarp and mesocarp (T3 and T4) were produced from younger fruits (with no degradation while on the ground).

Table 1: Tested treatments and storage times in a shed of charcoal from Attalea tessmannii fruits

\begin{tabular}{cccc}
$\begin{array}{c}\text { Tested } \\
\text { treatments }\end{array}$ & $\begin{array}{c}\text { Carbonization } \\
\text { date }\end{array}$ & $\begin{array}{c}\text { Parts of the } \\
\text { Fruits }\end{array}$ & $\begin{array}{c}\text { Drying } \\
\text { time }\end{array}$ \\
\hline T1 & December 2017 & Endocarp & 19 months \\
T2 & June 2018 & Endocarp & 13 months \\
T3 & December 2018 & Endo+mesocarp & 7 months \\
T4 & August 2019 & Endo+mesocarp & Newly produced \\
\hline
\end{tabular}


The collection of charcoal with different storage times was planned, aiming to analyze the variation in the moisture content of charcoal over time. Thus, it was possible to verify the influence of storage time on changes in the moisture content of charcoal. The variables evaluated in charcoal were: bulk density, immediate chemical analysis (moisture content, volatile materials content, ash content and fixed carbon content) and higher heating value.

With the exception of bulk density, all other properties were determined for all treatments. Bulk density was determined in a sample obtained from a mixture of the four treatments analyzed in the study. To determine bulk density, the charcoal contained in a $1 \mathrm{~m}^{3}$ box was weighed. For this, only an average of bulk density was obtained, without separation by dependent variable, unlike the other analyzed variables. The result of bulk density was obtained through the relationship between the mass and volume of the container, according to Equation 1:

$B D=\frac{m_{1-} m_{2}}{V}$

Where: $\mathrm{m}_{1}=$ sample mass + container $(\mathrm{g}) ; \mathrm{m}_{2}=$ container mass $(\mathrm{g}) ; \mathrm{v}=$ container volume $\left(\mathrm{cm}^{3}\right)$.

The immediate chemical analysis of charcoal from Attalea tessmannii fruits was performed according to ASTM D1762-84 (ASTM, 2013a) and moisture content (MC) according to NBR 14929 (Associação Brasileira de Normas Técnicas, 2003). The higher heating value was determined using an Ika C200 calorimeter, according to the procedure described in ASTM D5865 - 13 (American Society of Testing Materials, 2013b).

To assess the potential of charcoal from Attalea tessmannii fruits for domestic use, a comparison was made with charcoal from other species, commercialized for cooking food, obtained in the literature. We particularly looked into research papers that used charcoals from alternative species, charcoals from forest and industrial wastes, and charcoals from energy forests. The determination of quality for domestic use was based on the criteria established by the Premium Seal Resolution from São Paulo (São Paulo, 2015) (Table 2).

Table 2: Parameters for charcoal quality according to the Premium Seal of São Paulo.

\begin{tabular}{cc}
\hline Parameter & Reference value \\
\hline Bulk density (BD) & $>200 \mathrm{~kg} \mathrm{~m}^{-3}$ \\
Moisture content (MC) & $<5.0 \%$ \\
Ash content (AC) & $<1.5 \%$ \\
Fixed carbon content (FC) & $>73.0 \%$ \\
\hline
\end{tabular}

To analyze the results, a completely randomized design with three replications per treatment was used for the analysis of variance. In treatments that showed significant differences by the F test ( $p \leq 0.05)$; the means were compared by Tukey's test of means $(p \leq 0.05)$. To establish the correlation between the higher heating value and the immediate chemical composition of charcoal (volatile materials content, ash content and fixed carbon content), Pearson's correlation coefficient was applied.

\section{RESULTS AND DISCUSSION}

Bulk density of the charcoal from Attalea tessmannii fruits (Table 3) was higher than the reference value stipulated by Resolution $n^{\circ}$. 40/2015 of the Premium Seal of São Paulo (Table 2). The bulk density of the charcoal from Attalea tessmannii fruits is similar to the values found for charcoal from Attalea speciosa (babaçu), as they belong to the same botanical genus (Protásio et al., 2013). This similarity is due the morphological characteristics between the fruits of the two species. This variable also had a value similar to or higher than those obtained for wood charcoals (Table 3). 
Table 3: Bulk densities (BD) of charcoal from different types of biomass.

\begin{tabular}{ccc}
\hline Biomass & Bulk density $\mathbf{( \mathbf { k g ~ m }} \mathbf{- 3})$ & Author \\
\hline Charcoal from Attalea tessmannii fruits & 330 & Current study \\
Charcoal from Attalea speciosa & 340 & Protásio et al. (2013) \\
Charcoal from residues/mixed & 370 & Rosa et al. (2012) \\
Charcoal from mixed wood & 230 to 270 & Costa et al. (2017) \\
Charcoal from energy forest (eucalypt) & 156.41 to 355 & Donato et al. (2020) \\
\hline
\end{tabular}

Bulk density, along with true density, indicates the degree of efficiency of the carbonization process, influencing the porosity of charcoal. The higher the density, the lower the porosity. Thus, both variables influence thermal conductivity, time of heat supply and energy flow between charcoal pieces in barbecue equipment, influencing combustion and yield performance in the process of preparing food (Dias Júnior et al., 2020). In addition, Dias Júnior et al. (2020) emphasized the preference of consumers for barbecue charcoal with higher density.

In general, the charcoal from Attalea tessmannii fruits has high bulk density, which contributes to the good quality of the product in this respect, when considering the use for food cooking.

With respect to the moisture content (MC), with the exception of T3 treatment (Table 4), which had a higher moisture content, the other treatments fit into the Premium Seal Quality requirement parameters (São Paulo, 2015). As the variation between treatments was not statistically significant, differences in the moisture content observed between treatments can be attributed to variability within the material, since charcoal is a very hygroscopic material.

Table 4: Physical and energy properties of charcoal from Attalea tessmannii fruits.

\begin{tabular}{cccccc}
\hline Treatment & MC (\%) & VM(\%) & AC(\%) & FC(\%) & HHV ( $\left.\mathbf{k c a l ~} \mathbf{~ k g}^{-1}\right)$ \\
\hline T1 & $3.82^{\mathrm{a}}$ & $4.84^{\mathrm{b}}$ & $24.68^{\mathrm{a}}$ & $70.48^{\mathrm{a}}$ & $7,326^{\mathrm{b}}$ \\
T2 & $3.97^{\mathrm{a}}$ & $3.97^{\mathrm{b}}$ & $19.11^{\mathrm{a}}$ & $71.73^{\mathrm{a}}$ & $7,132^{\mathrm{c}}$ \\
T3 & $5.94^{\mathrm{a}}$ & $6.53^{\mathrm{ab}}$ & $22.30^{\mathrm{a}}$ & $71.17^{\mathrm{a}}$ & $7,332^{\mathrm{b}}$ \\
T4 & $3.14^{\mathrm{a}}$ & $8.44^{\mathrm{a}}$ & $16.51^{\mathrm{a}}$ & $75.05^{\mathrm{a}}$ & $7,502^{\mathrm{a}}$
\end{tabular}

Where: $\mathrm{MC}=$ moisture content; $\mathrm{VM}=$ volatile materials content; $\mathrm{AC}=$ ash content; $\mathrm{HHV}=$ higher heating value.

The analysis of the variation of moisture content related to storage time is important, since charcoal production is not the main economic activity in the community; but it is an income complementation. Therefore, storage of charcoal is a common practice to increase the amount of product to be marketed at the rights selling time. It is important to note that the values of moisture content remained low over the storage period and without significant variations between the different storage times. In a study carried out by Sousa et al. (2020), analyzing samples of charcoal from wood and fruit wastes from Attalea tessmannii in Acre state (Brazil), the authors obtained moisture contents of $6.74 \%$ and $4.22 \%$, respectively for the analyzed samples, the latter being very close to the moisture contents observed in this research.

Storage is done in places where there is a great variability of relative humidity. In the Amazon region, the dry and rainy periods are very intense. In the municipality of Tarauacá, Acre, Brazil, the rainy season is between October and April, and the dry season between June and August. In the interval from 1994 to 2019, the average annual precipitation was 2,288 $\mathrm{mm}$ $(1,642$ to $2,973 \mathrm{~mm})$. The lowest average temperatures throughout the year occurs in July $\left(24.9^{\circ} \mathrm{C}\right)$, while the highest ones occur in October $\left(26.6^{\circ} \mathrm{C}\right)$. In the period from December to March, typically rainy in Tarauacá, Acre, Brazil, the highest values of relative humidity occur; around $87.5 \%$, while in the dry period from June to August, relative humidity decreases, with a minimum in August, at approximately 79\% (Sousa, 2020). Considering these environmental conditions, coupled with the hygroscopic characteristic of charcoal, the samples showed stability in the moisture content during storage, which is a positive aspect of quality of this 
product. The moisture content of charcoal has an inverse relationship with the ease of ignition and with the formation of fines during storage (Dias Júnior et al., 2020). Charcoals with a higher moisture content will be difficult to start combustion and produce more smoke during the initial phase. Therefore, lower moisture contents are desired for a higher quality product.

Reis et al. (2015) found average moisture contents of $6.18 \%$ for charcoal from the coconut of Attalea speciosa, produced in an artisan way, with the same peculiarities of the production process used for the production of charcoal analyzed in this research. However, the authors did not take into account the storage conditions of the product. Attalea tessmannii and Attalea speciosa fruits are palm fruits of the same botanical genus and have similar morphology and bulk density, differing only in size. Therefore, even considering the morphological similarity, and the permanence in storage of the charcoal from Attalea tessmannii fruits, the latter had a lower moisture content.

As for the volatile materials content (VM), the lower, the better for charcoal for domestic consumption, aiming at the lowest amount of gases released during the preparation of food. However, Brahan (2002) considers the very low values of volatile materials, present in charcoal, to be a problem for ignition. In studies conducted by Griessacher et al. (2012) and Protásio et al. (2017) with carbonization of biomass from Attalea speciosa, the authors obtained volatile materials between 5 and $8 \%$ in carbonizations, with temperatures ranging from 650 to $850{ }^{\circ} \mathrm{C}$. In this context, with the use of masonry ovens for the production of charcoal in family farming it is possible to achieve temperatures near $450^{\circ} \mathrm{C}$ (Carvalho et al., 2020). However, although there were differences in carbonization temperatures, which influence the amount of volatile materials in charcoal, the results obtained in both studies were similar.

The influence of the parts of the fruits on the immediate chemical composition of the charcoal was clearly identified. The fruits used in the T1 and T2 treatments contained only the endocarp (VM 4.84\% and 3.97\%) and those used in T4 treatment, for being younger, had mesocarp and endocarp (VM 8.44\%). Therefore, charcoal that contained only endocarp had lower volatile contents. Teixeira (2008) described endocarp as the most important fruit component for production of charcoal, due to its differentiated chemical aspect compared to lignin and carbon contents of the other fruit components. Considering domestic use, the charcoal from Attalea tessmannii fruits will produce little flame and low emission of toxic materials. On the other hand, it is difficult for ignition. Charcoal producers have already observed the difficulty of ignition as a characteristic of the product. This leads to the need to add a firelighter in the packaging.

The ash contents (AC) shown in Table 4 did not fit the quality requirement parameters of the Premium Seal (São Paulo, 2015). The ash content of charcoal is related to the raw material from which it originated, consisting of inorganic elements that do not degrade in the carbonization process (Padilha et al., 2018). Because Attalea tessmannii charcoal is obtained from a fruit, the chemical and nutritional composition of this part of the plant can interfere with the AC. In addition to the natural ash content, the harvesting, storage and handling processes in the preparation of the raw material or in carbonization, during the stages of unloading from the oven, sieving and packaging of charcoal, can contribute to increasing the ash content due to external contamination. In general, the ash contents of the charcoal analyzed in this study are high.

Protásio et al. (2017), producing charcoal from Attalea speciosa, obtained ash contents ranging from 5 to $8 \%$, at tempearatures between 450 and $750{ }^{\circ} \mathrm{C}$. Reis et al. (2015) found an AC of $3.61 \%$ for Attalea speciosa coconut and $2.24 \%$ for sawmill waste. All of these had mean AC values much lower than those observed in the present research. Among the studies on quality of charcoal produced with other types of biomass, higher values of ash content (AC) were observed. Vale et al. (2011), evaluating the charcoal from Jatropha curcas, found high ash contents for charcoals from the epicarp $(25 \%)$ and cake $(10.43 \%)$, which is the co-product obtained after mechanical extraction of the oil from the seeds. The same authors stated that $A C$ values above $7 \%$ are considered high and that these are related to the presence of minerals from chemical fertilization of the soil. Despite the fact that Attalea tessmannii 
charcoal has high AC values, this factor does not limit its use in cooking food, it only represents a greater amount of residues in the burning equipment after use.

When comparing the results of fixed carbon content (FC) with the quality requirement parameters of the Premium Seal (São Paulo, 2015), which establishes 73\% of FC, only treatment T4 had values within the established criteria. Similar FC results for wood charcoal quality were found by Anater et al. (2019), who reported an average FC of $74.95 \%$. The mean FC values of the other treatments were higher than those found by Oliveira et al. (2015), with an average value of $68.21 \%$ and Brand et al. (2015), with an average TCF of $65.17 \%$. The FC values observed in charcoal from Attalea tessmannii fruit were closer to those found by Protásio et al. (2017). The same author, evaluating the laboratory carbonization of Attalea speciosa coconut (complete fruit) at a temperature of $450^{\circ} \mathrm{C}$ and temperatures above $650{ }^{\circ} \mathrm{C}$, obtained FC of $73 \%$ and $85 \%$, respectively.

The higher fixed carbon content makes it possible to prolong the burning time of fuel in equipment intended for energy conversion. This may result in increased efficiency in the use of heat produced by charcoal oxidation reactions (Protásio et al., 2017). The results of higher heating value (HHV) differed between the treatments of charcoal from Attalea tessmannii fruits (Table 4). Evaristo et al. (2016), in a study evaluating the energy potential of the macaúba palm fruit, found higher HHV $\left(7,859 \mathrm{kcal} \mathrm{kg}^{-1}\right)$ for endocarp than for epicarp $\left(7,464 \mathrm{kcal} \mathrm{kg}^{-1}\right)$, with higher values than in the present study. Despite the morphological similarity of Acrocomia aculeata (macaúba) fruit with Attalea tessmannii fruit, the behavior observed by Evaristo et al. (2016) did not occur in the latter species.

Charcoal from Attalea tessmannii fruit has a high energy potential, as its higher heating value $(\mathrm{HHV})$ ) is greater than that of charcoal produced from other fruits, leaves, shells and even from some wood species (Table 5). In general, as the HHV is directly linked to the quality potential of charcoal for domestic use, the higher the HHV, the better the charcoal, as it has more energy per unit of mass.

Pearson's correlation analysis between the higher heating value $(\mathrm{HHV})$ and the immediate chemical composition of charcoal demonstrated a strong, positive and significant correlation between the HHV and the content of volatile materials $(r=0.92)$. However, the fixed carbon content and the ash content had no significant correlation with the heating value.

Table 5: Higher heating value (HHV) of charcoal from different types of biomass.

\begin{tabular}{cccc}
\hline Biomass & Type & HHV (kcal kg $\mathbf{~}^{\mathbf{1}}$ ) & Source \\
\hline Charcoal from & Meso+endocarp & 7.323 & Current study \\
A. tessmannii fruits & endocarp & $6.926-7.165$ & Protásio et al. (2017) \\
Attalea speciosa & epicarp & 3.954 & Vale et al. (2011) \\
Jatropha & cake & 6.234 & Vale et al. (2011) \\
Jatropha & needle & 6.611 & Muñiz et al. (2014) \\
Pinus & shell & 7.067 & Padilha et al. (2018) \\
Coconut $\left(500^{\circ} \mathrm{C}\right)$ & & 7.193 & Soares et al. (2014) \\
Hybrid eucalypt (7 years) & Reforested & $7.643-7.665$ & Neves et al. (2011) \\
Eucalypt clones & wood & $7.290-7440$ & Protásio et al. (2013) \\
Eucalypt clones & & 6.248 & Medeiros Neto et al. \\
Caesalpinia pyramidalis (catingueira) & Native wood & 6.977 & (2014)
\end{tabular}

When performing a global analysis of the properties of charcoal from Attalea tessmannii fruits compared with other types of charcoal present on the market and already sold for cooking (Table 6), its low contents of moisture and volatile materials can be regarded as positive aspects, as well as its higher heating value. On the other hand, its high ash content can be highlighted as a disadvantage. 
Table 6: Comparison between Attalea tessmannii fruit charcoal with other charcoals for domestic use sold in different regions of Brazil: Acre, Santa Catarina, Paraná, Paraíba, Pará and Mato Grosso.

\begin{tabular}{|c|c|c|c|c|c|c|c|}
\hline Place of sale & Raw material & $\begin{array}{l}\text { MC } \\
(\%)\end{array}$ & $\begin{array}{l}\text { VM } \\
(\%)\end{array}$ & $\begin{array}{l}\text { AC } \\
(\%)\end{array}$ & $\begin{array}{l}\text { FC } \\
(\%)\end{array}$ & $\begin{array}{c}\text { HHV } \\
\left(\text { kcal kg }^{-1}\right)\end{array}$ & Source \\
\hline \multirow[t]{3}{*}{ Acre } & Attalea tessmannii fruit & 4.22 & 5.94 & 20.65 & 72.11 & 7,323 & Current study \\
\hline & Eucalyptus & 8.21 & 29.26 & 3.89 & 66.85 & 7,944 & \\
\hline & Acacia mearnsii & 7.00 & 35.76 & 0.81 & 63.43 & 7,448 & \multirow{3}{*}{ Brand et al. (2015) } \\
\hline \multirow[t]{2}{*}{ Santa Catarina } & Mixed wood & 8.59 & 27.67 & 3.44 & 68.79 & 4,301 & \\
\hline & $\begin{array}{l}\text { Eucalyptus and planted } \\
\text { Mimosa scabrella }\end{array}$ & 6.78 & 39.47 & 2.42 & 58.12 & 4,736 & \\
\hline Paraíba & Mixed wood & - & - & - & - & 7,655 & Monteiro et al. (2019) \\
\hline \multirow[t]{2}{*}{ Paraná } & Mixed wood & 5.79 & 22.93 & 2.12 & 74.96 & 7,321 & \multirow[t]{2}{*}{ Anater et al. (2019) } \\
\hline & Mixed wood - Brand A & 6.11 & 24.95 & 2.22 & 72.83 & 7,020 & \\
\hline \multirow[t]{2}{*}{ Pará } & Mixed wood - Brand B & 6.03 & 17.38 & 1.71 & 80.91 & 7,450 & \multirow[t]{2}{*}{ Oliveira et al. (2019) } \\
\hline & Mixed wood - Brand C & 6.27 & 19.31 & 2.58 & 78.11 & 7,375 & \\
\hline \multirow{2}{*}{ Mato Grosso } & Mixed wood - Brand 4 & 4.00 & 21.23 & 2.31 & 76.46 & 7,230 & \multirow{2}{*}{ Costa et al. (2017) } \\
\hline & Mixed wood - Brand 7 & 6.00 & 11.56 & 2.75 & 85.69 & 7,479 & \\
\hline Premium Seal & - & $>5.0$ & $>23.5$ & $>1.5$ & $<73$ & - & - \\
\hline
\end{tabular}

Where: $\mathrm{MC}=$ Moisture content; $\mathrm{VM}$ = volatile materials content; $\mathrm{AS}$ = ash content; $\mathrm{FC}$ = fixed carbon content; $\mathrm{HHV}=$ higher heating value.

Charcoal from Attalea tessmannii fruits, as it comes from a palm tree, is considered a nonwoody product. To obtain the fruits, there is no degradation of the native forest. Another important aspect is the fact that the carbonized part of the fruit constitutes wastes from the almond extraction process, which is characterized as the utilization of a resource that would otherwise be an untreated residue, which would generate pollution. It is important to emphasize that this charcoal is produced by traditional families and this non-woody product contributes to increasing their income. One aspect to increase the quality of the product would be the addition of a firelighter to the package, to improve its ignition property, which is hampered by the low content of volatile materials in the charcoal.

From the social aspect, the production of good quality charcoal and its sale will generate local income and improve the quality of life, in addition to the possibility of expanding the market for the product. Positive results generated in this research also contribute to the dissemination of information on the quality of charcoal, which can be used as a marketing tool for the product.

\section{CONCLUSION}

Charcoal produced from Attalea tessmannii fruits had low moisture content and volatile materials content and high bulk density, fixed carbon content and higher heating value, but high ash content. When compared to charcoal already sold for domestic use, charcoal from Attalea tessmannii fruits showed high quality potential to be included in the market.

Regarding the importance of the product as a supplement to the income of the traditional community involved in its production, storage is an important factor to increase the volume of product to be sold. Thus, storage can be carried out without influencing to the quality of the product, as it does not affect the moisture content of charcoal over time.

The low contents of volatile materials that reduce the ignition power leads to the need to develop a firelighter, which, if added to the packaging, would reduce the impact of this property on the product.

\section{REFERENCES}

American Society of Testing Materials - ASTM International. (2013a). ASTM D1762-13: standard test method for chemical analysis of wood charcoal. West Conshohocken: ASTM International.

American Society of Testing Materials - ASTM International. (2013b). ASTM D5865-13: standard test method for gross calorific value of coal and coke. West Conshohocken: ASTM International. 
Anater, M. J., Sanquetta, C. R., Brand, M. A., Silva, D. A., \& Corte, A. P. D. (2019). Análise da qualidade do carvão vegetal para uso residencial na região de Curitiba, Paraná, Brasil. Scientia Forestalis, 47(123), 494-504. http://dx.doi.org/10.18671/scifor.v47n123.11.

Associação Brasileira de Normas Técnicas - ABNT. (2003). NBR 14929: Madeira - Determinação do teor de umidade de cavacos - Método por secagem em estufa. Rio de Janeiro: ABNT.

Brahan, W. K. Combustibilidad de la madera: la experiência com espécies colombianas. Bogotá: Fondo de Publicaciones, 2002.

Brand, M. A., Rodrigues, A. A., Oliveira, A. D., Machado, M. S., \& Zen, L. R. (2015). Qualidade do carvão vegetal para o consumo doméstico comercializado na Região Serrana Sul de Santa Catarina. Revista Árvore, 39(6), 1165-1173. http://dx.doi.org/10.1590/0100-67622015000600020.

Carvalho, A. F., Brand, M. A., Higuchi, P., \& Silva, A. C. (2020). Qualidade do carvão vegetal obtido a partir da espécie Cecropia glaziovii Sneth. produzido na agricultura familiar em Santa Catarina. Revista de Ciências Agroveterinárias, 19(1), 132-138. http://dx.doi.org/10.5965/223811711912020132.

Costa, A. C. S., Oliveira, A. C., Freitas, A. J., Leal, C. S., \& Pereira, B. L. C. (2017). Qualidade do carvão vegetal para cocção de alimentos comercializado em Cuiabá-MT. Nativa, 5(6), 456-461. http://dx.doi.org/10.5935/2318-7670.v05n06a12.

Dias Júnior, A. F. D., Andrade, C. R., Lana, A. Q., Silva, Á. M., Brito, J. O., \& Milan, M. (2021). Tips on the variability of BBQ charcoal characteristics to assist consumers in product choice. European Journal of Wood and Wood Products, 79(4), 1-10. http://dx.doi.org/10.1007/s00107-021-01659-5.

Dias Júnior, A. F., Andrade, C. R., Brito, J. O., Lira, S. P., Andrade, A. M. D., \& Souza, N. D. D. (2017). Hidrocarbonetos policíclicos aromáticos no composto orgânico extraído do carvão vegetal utilizado para cocção de alimentos. Revista Árvore, 41(5), 1-9.

Dias Júnior, A. F., Andrade, C. R., Milan, M., Brito, J. O., Andrade, A. M. D., \& Souza, N. D. D. (2020). Quality function deployment (QFD) reveals appropriate quality of charcoal used in barbecues. Scientia Agrícola, 77(6), 1-11. http://dx.doi.org/10.1590/1678-992x-2019-0021.

Dias Júnior, A. F., Brito, J. O., \& Andrade, C. R. (2015). Influência da granulometria na combustão do carvão vegetal utilizado para cocção de alimentos. Revista Árvore, 39(6), 1127-1133.

Donato, D. B., Carneiro, A. D. C. O., Carvalho, A. M. L. M., Vital, B. R., Milagres, E. G., \& Canal, W. D. (2020). Influência do diâmetro da madeira de eucalipto na produtividade e propriedades do carvão vegetal. Revista Ciência da Madeira, 11(2), 63-73. http://dx.doi.org/10.12953/21776830/rcm.v11n2p63-73.

European Committee for Standardization. (2005). CSN EN 1860-2 - Appliances, solid fuels and firelighters for barbecueing - Part 2: Barbecue charcoal and barbecue charcoal briquettes - Requirements and test methods. Brussels: CEN. 26 p.

Evaristo, A. B., Martino, D. C., Ferrarez, A. H., Donato, D. B., Carneiro, A. D. C. O., \& Grossi, J. A. S. (2016). Potencial energético dos resíduos do fruto da macaúba e sua utilização na produção de carvão vegetal. Ciência Florestal, 26(2), 571-577. http://dx.doi.org/10.5902/1980509822757.

Griessacher, T., Antrekowitsch, J., \& Steinlechner, S. (2012). Charcoal from agricultural residues as alternative reducing agent in metal recycling. Biomass and Bioenergy, 39, 139-146. http://dx.doi.org/10.1016/j.biombioe.2011.12.043.

Lima, E., Felfili, J. M., Marimon, B. S., \& Scariot, A. (2003). Diversidade, estrutura e distribuição espacial de palmeiras em um cerrado sensu stricto no Brasil Central-DF. Revista Brasileira de Botanica, 26(3), 361-370. http://dx.doi.org/10.1590/S0100-84042003000300009.

Medeiros Neto, P. N., Oliveira, E., \& Paes, J. B. (2014). Relações entre as características da madeira e do carvão vegetal de duas espécies da Caatinga. Floresta e Ambiente, 21(4), 484-493. http://dx.doi.org/10.1590/2179-8087.051313.

Monteiro, M. M., Neto, P. N. M., Martins, K. B. S., Melo, J. L. D., Medeiros, N. C. G., \& Souza Junior, C. M. P. (2019). Determinação do poder calorífico do carvão vegetal comercializado no centro da cidade de Patos-PB. Agropecuária Científica no Semiárido, 15(3), p. 176-178.

Muñiz, G. I. B. D., Lengowski, E. C., Nisgoski, S., Magalhães, W. L. E. D., Oliveira, V. T. D., \& Hansel, F. (2014). Characterization of Pinus spp needles and evaluation of their potential use for energy. Cerne, 20(2), 245-250. http://dx.doi.org/10.1590/01047760.201420021358.

Neves, T. A., Protásio, T. P., Couto, A. M., Trugilho, P. F., \& Silva, V. O. (2011). Avaliação de clones de Eucalyptus em diferentes locais visando à produção de carvão vegetal. Pesquisa Florestal Brasileira, 31(68), 319-330. http://dx.doi.org/10.4336/2011.pfb.31.68.319. 
Oliveira, A. F., Bavaresco, A., Pessuti, C. A. A., Miyashiro, C. S., \& Frank, J. (2015). Análise da qualidade do carvão para consumo doméstico de quatro municípios do estado do Paraná. Revista Brasileira de Energias Renováveis, 4(3), 102-111. http://dx.doi.org/10.5380/rber.v4i3.43034.

Oliveira, R. S., Silva, L. F. F., Andrade, F. W. C., Trugilho, P. F., Protásio, T. P., \& Goulart, S. L. (2019). Qualidade do carvão vegetal comercializado no Sudeste Paraense para cocção de alimentos. Amazonian Journal of Agricultural and Environmental Sciences, 62, 1-9. http://dx.doi.org/10.22491/rca.2019.3017.

Padilha, E. R. D., Belini, G. B., Nakashima, G. T., Waldman, W. R., \& Yamaji, F. M. (2018). Potencial energético da casca de coco (Cocos nucifera L.) para uso na produção de carvão vegetal por pirólise. Revista Virtual de Química, 10(2), 334-345. http://dx.doi.org/10.21577/1984-6835.20180026.

Protásio, T. P., Bufalino, L., Tonoli, G. H. D., Guimarães Junior, M., Trugilho, P. F., \& Mendes, L. M. (2013). Brazilian lignocellulosic wastes for bioenergy production: characterization and comparison with fossil fuels. BioResources, 8(1), 1166-1185. http://dx.doi.org/10.15376/biores.8.1.1166-1185.

Protásio, T. P., Guimarães Junior, M., Mirmehdi, S., Trugilho, P. F., Napoli, A., \& Knovack, K. M. (2017). Combustion of biomass and charcoal made from babassu nutshell. Cerne, 23(1), 1-10. http://dx.doi.org/10.1590/01047760201723012202.

Reis, A. R. S., Reis, J. S. F., Silva, J. R., Carvalho, J. C., Souza, D. V., \& Reis, L. P. (2015). Comparação entre carvão de coco Attalea speciosa e carvão de resíduos madeireiros comercializados em Altamira - PA. Ciência da Madeira, 6(2), 100-106. http://dx.doi.org/10.12953/2177-6830/rcm.v6n2p100-106.

Rosa, R. A., Arantes, M. D. C., Paes, J. B., Andrade, W. S. P., \& Moulin, J. C. (2012). Qualidade do carvão vegetal para o consumo doméstico. Journal of Biotechnology and Biodiversity, 3(2), 41-48. http://dx.doi.org/10.20873/jbb.uft.cemaf.v3n2.rosa.

São Paulo. Secretaria de Agricultura e Abastecimento. (2015). Resolução nº 40 SAA, de 14 de dezembro de 2015 (SAA Resolution 40, of December 14, 2015). Diário Oficial do Poder Executivo. São Paulo. Retrieved in 2021, April 06, from: http://www.codeagro.agricultura.sp.gov.br/arquivos/selo/SAA\%2040\%20Carvao\%20Vegetal\%202015.pdf.

Secretaria do Meio Ambiente - SEMA. (2010). Programa Estadual de Zoneamento Ecológico Econômico Fase II: documento Síntese - Escala 1:250.000. Rio Branco: SEMA.

Secretaria do Meio Ambiente - SEMA. (2019). Plano de manejo do complexo de florestas estaduais. Rio Branco: SEMA.

Silva, J. C., Barrichelo, L. E. G., \& Brito, J. O. (1986). Endocarpos de babaçu e de macaúba comparados a madeira de Eucalyptus grandis para a produção de carvão vegetal. IPEF, 34, 31-34.

Soares, V., Bianchi, M. L., Trugilho, P. F., Pereira, A. J., \& Höfler, J. (2014). Correlações entre as propriedades da madeira e do carvão vegetal de híbridos de eucalipto. Revista Árvore, 38(3), 543549. http://dx.doi.org/10.1590/S0100-67622014000300017.

Sousa, A. N. S., Pereira, K. R. M., \& Xavier, C. N. (2020). Estudo comparativo de qualidade de carvões vegetais oriundos de diferentes biomassas. In / Seminário online: Tecnologias e inovações de produtos florestais. Rio Brando: Universidade Federal do Acre. Retrieved in 2021, November 11, from https://doity.com.br/anais/i-seminrio-online-tecnologias-e-inovaes-de-produtosflorestais/trabalho/161031.

Sousa, J. W. (2020). Variabilidade de elementos meteorológicos no município de Tarauacá, Acre, intervalo 1994 - 2019. Scientia Naturalis, 2(2), 692-707.

Stachiw, R., Ribeiro, S. B., Jardim, M. A. G., Possimoser, D., Alves, W. D. C., \& Cavalheiro, W. C. S. (2016). Potencial de produção de biodiesel com espécies oleaginosas nativas de Rondônia, Brasil. Acta Amazonica, 46(1), 81-90. http://dx.doi.org/10.1590/1809-4392201501151.

Teixeira, M. A. (2008). Babassu: a new approach for an ancient Brazilian biomass. Biomass and Bioenergy, 32(9), 857-864. http://dx.doi.org/10.1016/j.biombioe.2007.12.016.

Vale, A. T., Mendes, R. M., Amorim, M. R. S., \& Dantas, V. F. S. (2011). Potencial energético da biomassa e carvão vegetal do epicarpo e da torta de pinhão manso (Jatropha curcas). Cerne, 17(2), 267-273. http://dx.doi.org/10.1590/S0104-77602011000200015.

Authors' contributions: ANSS: Conceptualization, data curation, formal analysis, investigation, methodology, writing - original draf, writing - review \& editing; KRMP: Conceptualization, data curation, formal analysis, investigation, methodology, project administration, supervision, validation, writing - original draf, writing - review \& editing; AFDJ: Conceptualization, data curation, formal analysis, investigation, methodology, validation, visualization, writing - original draf, writing - review \& editing; MBF: validation, visualization, writing - original draf; MAB: formal analysis, validation, visualization, writing - original draf, writing - review \& editing. 